\author{
Review

\section{Bone morphogenetic proteins (BMPs): how do they function and what can they offer the clinician?} \\ Nikitas Sykaras ${ }^{\S}$ and Lynne A. Opperman ${ }^{\dagger}$ \\ ${ }^{\S}$ Department of Fixed Prosthodontics, Dental School, Athens University, Athens, Greece \\ Department of Biomedical Sciences, Texas A\&M University System, \\ Health Science Center, Baylor College of Dentistry, Dallas, Texas, USA
}

(Received 10 February and accepted 28 May 2003)

\begin{abstract}
Bone Morphogenetic Proteins (BMPs) form a unique group of proteins within the Transforming Growth Factor beta (TGF-ß) superfamily of genes and have pivotal roles in the regulation of bone induction, maintenance and repair. They act through an autocrine or paracrine mechanism by binding to cell surface receptors and initiating a sequence of downstream events that have effects on various cell types. Differentiation of osteoprogenitor mesenchymal cells and up-regulation of osteoblastic features occur under the influence of cytokines and growth factors that are expressed with the direct or indirect guidance of BMPs acting at the transcriptional level or higher. The Smads family of proteins has been identified as the downstream propagator of BMP signals, whereas hedgehog genes are possible modulators of BMP expression. The inflammatory response observed during wound repair and fracture healing, results in by-products that interact with BMPs and affect their biologic potential. Additive, negative or synergistic effects are observed when homodimeric or heterodimeric forms of BMPs interact with BMP receptors. Storage within the bone matrix allows for their involvement in the modeling/remodeling process by mediating coupling of osteoblasts and osteoclasts. Micro-environmental conditions, dose, possible carrier materials and geometrical parameters of delivery matrix are critical determinants of the
\end{abstract}

Correspondence to Dr. Nikitas Sykaras, Nikis 25 str., Marousi 15125, Athens, Greece.

Tel/Fax: 011-30-2106800636

E-mail: nsykaras@ otenet.gr

This project is part of a dissertation prepared in partial fulfillment of the requirements for the Degree of Doctor of Philosophy. (N. S.) pharmacokinetics of BMP action and the biologic outcome during wound repair. Because of their osteogenic potential, BMPs are of tremendous interest as therapeutic agents for healing fractures of bones, preventing osteoporosis, treating periodontal defects and enhancing bone formation around alloplastic materials implanted in bone. (J. Oral Sci. 45, 57-73, 2003)

Key words: bone morphogenetic proteins; bone; growth factors; delivery systems; therapeutic regeneration.

\section{Introduction}

Bone Morphogenetic Proteins (BMPs) form a unique group of proteins within the Transforming Growth Factor beta (TGF- $\beta$ ) superfamily. BMPs were first identified by Urist in 1965 when demineralized bone matrix implanted in ectopic sites in rats was found to induce bone formation (1). There is extensive evidence supporting their role as regulators of bone induction, maintenance and repair, as well as being critical determinants of the embryological development of mammalian organisms $(2,3)$. During embryogenesis, they regulate dorsal-ventral patterning (4), establishment of embryonic body plan (4), cell apoptosis (5), differentiation of neural cells $(6,7)$, patterning of the limb bud (5) and epithelial-mesenchymal interactions during organogenesis $(8,9)$. The TGF- $\beta$ superfamily includes the activins/inhibins, BMPs, TGF- $\beta$, growth and differentiation factors (GDFs), mullerian inhibiting substance, Drosophila dpp and Xenopus Vgl, amongst others (10). BMPs play a role in the differentiation, proliferation, growth inhibition and arrest of maturation 
of a wide variety of cells, depending on the cellular microenvironment and the interactions with other regulatory factors (11).

\section{Ligand-receptor interactions and downstream events}

At their carboxy-terminal ends, all BMPs posses a region containing seven cysteine residues that is conserved among all the reported members of the TGF- $\beta$ superfamily (12). BMPs are synthesized inside the cell in a precursor form with a hydrophobic secretory leader and a propeptide sequences joined to the mature region. Proteolytic cleavage frees the mature region, which can then dimerize with other BMPs. Mature BMP-2 is a homodimer of two 114-peptides subunits (13). Dimeric molecules can be either homodimers, when both subunits are the same, or heterodimers, consisting of two different subunits. Structural and chemical differences between the homodimeric and heterodimeric forms may be responsible for variations of their biologic potential and binding characteristics.

BMPs initiate signaling from the cell surface when they bind to and bring together type I and type II serinethreonine kinase receptors $(14,15)$, both of which have subcategories (17). BMP receptors are composed of three parts: a short extracellular domain, a single membrane-spanning domain, and an intracellular domain with the active serine/threonine region (18). The $75 \mathrm{kDa}$ type II receptor is the primary binding site of the ligand and upon its activation, phosphorylation of the type I receptor (50-55 $\mathrm{kDa}$ ) occurs $(14,17)$. It is only after the type I receptor becomes phosphorylated that receptor signals are propagated to downstream substrates (9). It is believed that the type II receptor does not actually bind the ligand but rather stabilizes the type I receptor (19), or accelerates ligand binding to the type I receptor (20).

Various signaling pathways have been proposed to be activated by the ligand binding to the receptors. Recently, a novel family of proteins, the Smad family, have been identified as the downstream effectors of the phosphorylated type I receptor (21-23). More specifically, Smads 1 and 5 become phosphorylated at the carboxy-terminal serine residues and then translocate to the nucleus (24) where they interact with DNA binding proteins (25), or exhibit direct transcriptional activity (26), either as monomers or in association with Smad 4 (21). Specific Smads are expressed at different phases of the cell cycle and exhibit either an inhibitory or stimulatory function (27). Smads 6/7 have been shown to antagonize and inhibit phosphorylation of Smads $1 / 5$ by BMP-2 $(28,29)$. Phosphorylation of Smad 1 leads to the transcriptional activation of the DPC4 gene that expresses Smad4 and the subsequent Smad1/4 complex translocates to the nucleus (21). The lack of DNA binding motifs on Smads does not allow their direct association with genomic sequences. It has been shown that small interacting proteins are necessary in bridging molecules and helping to mediate Smads action.

Genetic screens in Drosophila revealed that the gene schnurri becomes up-regulated after BMP binds to their receptors, leading to the formation of an active transcription factor similar to zinc finger proteins in mammals (30). In addition, the protein kinase TAK1 has been isolated and shown to transduce signals downstream following BMP binding and function as a mitogen-activated protein kinase (31). Overall, BMPs regulate cell function at the transcriptional level or higher (32), by increasing the rate of transcription and/or stabilizing the mRNA (33). Moreover, the large number (2,500/cell) of BMP receptors (6) and their variability $(16,29)$ allows heteromeric complexes to be formed with different signaling potential (16) capable of inducing various responsive cascades when binding to the same ligand $(29,34)$.

Another line of evidence indicates the involvement of the Ras/Raf pathway in the downstream response to BMPs (35). According to this model, the signal is transmitted through Ras to Raf and, subsequently, activates other transcription factors such as AP-1 and GATA-2. BMP-2 up-regulates Id (inhibitor of differentiation) gene expression in osteoblastic cells and promotes their specific phenotypic expression (32). BMP-2 has an effect on cell-matrix interactions by suppressing the expression of the (3 integrin subunit at the mRNA level (36), suggesting that BMP action, in part, may be exerted through altered cell adhesion to the extracellular matrix (ECM), modified cell migration and differentiation $(37,38)$. In another report, cadherin expression in osteoblasts was unaffected by BMP-2 suggesting that the latter does not play a role in cell-cell interactions (39).

The family of Hedgehog genes (Sonic hedgehog, (Shh), Desert hedgehog, (Dhh) and Indian hedgehog, (Ihh)) present a striking correlation with expression of BMP genes in the mouse embryo (40) and act as possible modulators of BMP expression (41). In addition, growth factors such as TGF- $\beta 1$ exert a negative regulation on BMP-2 at the transcription level (42) and retinoic acid receptors also affect BMP expression (43). Noggin, chordin, cerberus, dan and gremlin are some of the molecules that have recently been found to regulate BMP expression and modulate their role in eliciting various biologic responses (44). A number of BMP-binding proteins (lipovitellin 1, Ep45) (45) and antagonist molecules (noggin) (46), affect and control the presence of growth 
factors thus defining various concentration gradients, which has been shown to play a role in cytodiferentiation. There are several reports on the associated action of BMPs and noggin $(47,48)$ suggesting that transcription factors from the fos family are downstream targets of nogginrelated calcium regulation (47). These transcription products in turn limit the stimulatory action of BMPs on osteoblasts and thus act as autocrine regulators (49).

In summary, the variety of BMP receptors and the numerous pathways they regulate, together with the fact that BMPs exist in the form of homodimers, suggest that they may evoke synergistic, negative or additive net effects. This draws attention to the complexity of the signaling cascade and the variability of downstream responses to BMP-receptor signaling.

\section{BMPs in bone formation}

Bone formation can take place via a direct (intramembranous) or an indirect (endochondral) process. Intramembranous ossification occurs during embryonic development of the cranial vault bones by the direct transformation of mesenchymal cells into osteoblasts. Endochondral ossification, which is the process by which long bones develop, involves the formation of an intermediate cartilaginous anlagen that eventually becomes ossified and contains all the cellular components of mature bone (50). In both mechanisms, the induction of bone and cartilage occurs through an epithelial-mesenchymal interaction (51) that initiates specific cell differentiation and leads to precursor cells of the osteoblastic or chondroblastic lineage.

The development of cartilage and bone from mesenchyme, is characterized initially by a condensation of mesenchymal cells (52). This condensation can occur in two ways: either by cells moving toward a central focal point or by a localized region of increased proliferation. Direct cell-to-cell contact, diffusible molecules produced by the signaling cells, or matrix mediated interactions can result in a cellular mass of increased proliferative activity (53-55). An early step in the endochondral bone formation process is the condensation of mesenchymal cells into discrete pre-cartilaginous nodules. Chondrogenic cells become hypertrophic and pass into a bio-synthetically active state that involves mineral deposition in the cartilaginous matrix. The hypertrophic chondrocytes will then secrete chemotactic agents that both attract and direct the invasion of the sites by blood vessels. The chondrocytes eventually die and their matrix is partially destroyed during vascular invasion, which is when osteoblasts appear. Initially, osteoid will be deposited and remodeling will finally produce functional bone tissue (56).
Glucocorticoids mediate their action on osteoblasts through BMPs (57) and retinoic acid, a derivative of vitamin A, is a possible modulator of BMP expression (58). Cell adhesion molecules such as laminins (59), neural cell adhesion molecules (N-CAM) (60), and integrins (36) are known to interact with BMPs and other growth factors and have been localized at the areas of initial mesenchymal condensation $(60,61)$. Related to this intra-molecular interaction are the chemotactic properties of BMPs. Depending on their concentration gradient, BMPs can attract various types of cells $(19,62)$ and act as chemotactic, mitogenic or differentiating agents $(63,64)$. BMPs may affect proliferation of cartilage-forming and bone-forming cells and can induce differentiation of mesenchymal progenitor cells into various cell types, including chondroblasts and osteoblasts $(19,65)$. The latter property suggests that BMPs may be able to influence both the endochondral bone induction pathway and direct bone formation. In ectopic bone formation, associated with implantation of BMPs, the sequence of events recapitulates the process of bone formation that is observed during embryonic long bone development and many of the BMP properties can be extrapolated from there.

One of the most difficult subjects to study with regard to the in vivo response to BMPs is the characterization of the responding cell population. The wide spectrum of cells that are sensitive to BMP action includes fibroblasts (61), mesenchymal connective tissue cells (66), muscle derived connective tissue cells (67), the astroglial lineage (68) and many more (61). Bone marrow stromal cells form an important source of mesenchymal pluripotential progenitors that are capable of differentiating into various cell lineages under the appropriate conditions. Demineralized bone matrix, dexamethazone, beta glycerophosphate, vitamin D and BMP-1 have been shown to stimulate bone marrow stromal cells to take on an osteoblastic phenotype $(69,70)$. Bone marrow mesenchymal cells have the potential to differentiate along the osteoblastic and adipocytic lineages. Studies have demonstrated a concentration specific response with lower doses of BMPs inducing the adipocyte lineage and higher doses eliciting a chondrogenic/osteoblastic response (71). Treatment with rhBMP-2 protects and enhances cell commitment towards the osteoblastic phenotype $(72,73)$. Osteoblasts and chondroblasts originate from a common precursor which is a bipotential mesenchymal progenitor called osteo-chondroprogenitor (74) or skeletoblast (75-78). Osteoprogenitors can be classified as either determined or inducible, based on their need for additional signals in order to differentiate $(58,79)$. This difference is important as it reflects the variation between cell commitment, when the fate of cells is 
programmed, and cell differentiation, when the fate of cells is expressed due to the permissive signals of the micro-environment. The answer to this debate is not clear yet but it is obvious that some form of control over phenotypic expression must occur to ensure that the tissues develop in a coordinated fashion in the appropriate places and amounts. (80). Evidence supports the hypothesis that BMPs act on the skeletal progenitor cells and induce the differentiation of both the osteoblast $(65,71,81-83)$ and chondroblast $(56,60,84,85)$.

Factors affecting BMPs bone inductive ability are amounts, qualitative composition, possible presence of inhibitors, correct processing and storage (86). In addition, the dose, concentration and time of BMP action are important parameters of the inductive outcome $(64,87)$. Low concentrations of BMP-2 $(50 \mathrm{ng} / \mathrm{ml})$ up-regulated the expression of the collagen II gene whereas higher concentrations $(100-400 \mathrm{ng} / \mathrm{ml})$ inhibited collagen II expression in chondrocyte cell lines and increased osteocalcin (OC) expression (72). These results clearly show that chondrocytes are able to express osteoblastic features. It is more realistic to assume that BMPs induce cytodifferentiation along those lineages when permissive conditions for each cell type exist. Stability or structural integrity that allows blood vessels to grow (88), microenvironmental conditions that affect oxygen tension (89), and geometrical/architectural characteristics of the ECM affecting the cytoskeleton (90) through membrane receptors are critical factors for cytodiferentiation. Differences in the partial pressure oxygen and in the amount of mesenchymal cells present in intramuscular and subcutaneous sites are responsible for the lower dose of BMP needed to induce ectopic bone formation in the former site (91).

Treatment with cytochalasin D disrupts the cytoskeleton, making cells spherical in shape and resulting in high concentrations of endogenous soluble and matrix factors, thus promoting the chondrogenic phenotype (92). Reduced serum, high cell density, and type I collagen have been described as necessary parameters for chondrogenic differentiation (93). Cells at high density become attached to type I collagen leading to cellular condensation that promotes the chondrogenic phenotype. Further differentiation into hypertrophic chondrocytes and mineralization does not require BMP-2 but it is dependent on the presence of ascorbic acid and serum factors $(94,95)$. Depending on the dose and the coordinated action of other cytokines $(100,101)$, BMP-2 plays a regulatory role for the sequential progression of chondrocytes through their maturation $(96,97)$, with development of hemopoietic bone marrow $(98,99)$, and inhibition of myogenic differentiation (83). Differentiation of mesenchymal cells into pre-chondroblasts is induced by BMPs but the coordinated progression along the chondroblastic and subsequent osteoblastic lineage is regulated by other growth factors that work in an autocrine or paracrine manner (102). BMPs acting through an autocrine mechanism reduce the expression of collagenase- 3 and noggin, thereby inhibiting BMP binding and function and, result in increased production of collagenase-3 (103). Although BMPs exert their action on both osteoblasts and chondroblasts, they do not change the fate of the respective progenitors (104). Early exposure of undifferentiated mesenchymal cells to BMPs induces the chondroblastic pathway, whereas later exposure accelerates osteoblastic differentiation (105). BMPs can stimulate osteoblast differentiation independently of cartilage formation (106). This means that in the case of endochondral bone formation, osteoblasts do not form from a transdifferentiation of chondrocytes but rather as a result of a separate induction $(1,70,93,107)$. Endothelial cells invading the cartilage may serve as a homing target of the stem cells that later develop into pre-osteoblasts (98). Numerous reports show an up-regulation of the osteoblastic phenotype by BMPs. Up-regulation of osteocalcin (OC), osteopontin (OP), osteonectin, bone sialoprotein (BSP), alkaline phosphatase (ALP), receptors for parathyroid hormone, collagen I production and the rate of mineralization are all proof of a promotive effect of BMPs on mesenchyme-derived cells $(64,82,86,106,108,109)$. BMPs can act on various cell types and elicit a response that is specific to that stage of cell differentiation (106). There is evidence that BMPs trigger the production of osteopontin in preosteoblasts whereas in osteoblastic cells osteocalcin is upregulated and bone sialoprotein is expressed in differentiated osteoblasts prior to mineralization (110).

BMPs play an important role in the process of bone modeling and remodeling. The morphogenetic activity of bone matrix is apparent only after its demineralization, which occurs with the controlled action of osteoclasts. Insulin-like growth factors (IGF-I, IGF-II), TGF $\beta-1$, TGF $\beta$ 2, PDGF, basic and acidic fibroblast growth factors, BMPs and other molecules are produced and become incorporated into the forming bone matrix that serves as a reservoir (111). BMPs bind to collagen type IV (112) or type I (113) and under these conditions are inactive. A heparin-binding site has been identified at the N-terminal segments of the BMP-2 that may function to localize the growth factor and restrict its diffusion (13). Acid treatment associated with osteoclastic action liberates BMPs from their collagenous substrate rendering them biologically active (114) and able to affect cell proliferation and differentiation (70). 
Guided streaming of specific cell types into the appropriate pathways makes BMPs important regulators of bone formation (113), with a pivotal role in bone remodeling (110). "Basic Multicellular Units" (BMUs) refer to the functional units of bone in which osteoblasts and osteoclasts act in coordination (115). This is called coupling. During remodeling, which is a "self-maintenance" process, existing bone is resorbed and new bone is deposited. Resorption during each remodeling cycle is balanced by an equal amount of bone formation since the amounts of BMPs and other growth factors released from bone are proportional to the extent of resorption $(116,117)$. There is evidence that BMP-2 promotes expression of cyclooxygenase- 2 and the osteoclast differentiation factor in osteoblast-like cells, thus regulating osteoclastogenesis (118). Based on the above, the mitogenic, chemotactic and differentiating effect of BMPs may help to mediate coupling of bone formation to resorption during the adaptive response of remodeling. It supports the cellular components and amplifies the molecular signals needed for the coordinated interaction of various cell types.

\section{BMPs in fracture healing}

Fracture healing involves complex interactions among many local and systemic regulatory factors as well as cell types that cluster at the fracture site. Fracture repair represents a situation in which cell differentiation is reinitiated in an otherwise mature organism (2). Mesenchymal stem cells congregate at the area and form a gap-spanning, highly cellular "repair blastema" $(119,120)$. The principal phases during ectopic bone induction are the migration and attachment of progenitor mesenchymal cells, proliferation, differentiation into cartilage or bone cell lineages, mineralization and remodeling, and marrow tissue formation.

The first demarcation of osteoprogenitor cells during fracture repair, referred to as the "stacked-cell layer" (120), is derived from mesenchymal stem cells (119). They are brought into the fracture area under the influence of paracrine or autocrine mechanisms (121) and then differentiate into pre-osteoblasts. In the case of bone fracture where there is a substantial gap between the originally continuous bone, a sequence of cellular and molecular events is initiated in response to the trauma, including inflammation, repair and remodeling (122). Injury leads to blood-clot formation that results in lysis of platelets, releasing numerous growth factors. The blood clot then begins to organize and the formation of a provisional callus that bridges the fracture site becomes apparent. Increased vascular permeability allows fluid and plasma proteins to leave the blood vessels. Various cell types then emerge from the vessels in significant numbers. In acute inflammation, neutrophils (PMNs) are the first leukocytes to provide an effective defense in response to the trauma.

$\mathrm{PGE}_{1}$ has a strong and dose-dependent promotive effect on the osteogenic activity of rhBMP (123), and glucocorticoids exert similar effects (69) whereas binding of BMP to free heparin at the fracture site could help to localize the growth factor by restricting its diffusion (13). Another component of the inflammatory process is the acidic conditions that develop and, together with the proteolytic fragments of the plasminogen system, help activate latent forms of growth factors such as TGF- $\beta 1$ and regulate a positive feed-back system that amplifies activation of TGF- $\beta 1$ from platelets, thus stimulating cartilage and bone formation (113). BMPs can also induce chemotaxis of monocytes and stimulate their expression of TGF- $\beta 1$ mRNA (62). Finally, blood-clot formation following tissue injury results in the lysis of platelets that release numerous growth factors that are involved in wound healing and contribute to bone repair (121).

Depending on the mechanical stability of the fracture, mesenchymal stem cells can differentiate into chondroblasts or osteoblasts. If the fracture is mechanically unstable, cartilage will form and the bone fragments will be mechanically joined. If the fracture is mechanically stable, the chondrocytes within the blastema become hypertrophic, and along with their extracellular matrix, become eroded and replaced by osteoblasts and osteoid deposits $(119,120)$. This process is similar to the one observed in embryonic long bone development. If the original break is mechanically stable, the repair blastema can be spanned by vasculature and the mesenchymal cells differentiate directly into secretory osteoblasts $(119,120)$. Mesenchymal stem cells may originate from the periosteum, the marrow space or are brought to the repair site via the circulatory system. Although the exact origin is not determined, the important fact is that mesenchymal cells will be attracted to the fracture site and play an important role in the repair process (124).

The inflammatory response acts as a multipotential modulator and initiator of the repair process, using mechanisms that will be described later, and as such must be considered a necessary event for the healing of bone wounds. TGF- $\beta 1$ is an important and multifunctional autocrine regulator of bone formation (125). It has been demonstrated that TGF- $\beta 1$ downregulates alkaline phosphatase, osteocalcin, osteopontin, collagen I and BMP-2 mRNA expression. This provides evidence that TGF- $\beta 1$ acts as a powerful bone growth stimulant at the level of pre-osteoblasts (126), which is needed for the 
coordinated progression of cell types along their differentiation pathways (127). TGF- $\beta 1$ stimulates DNA synthesis and replication of osteoprogenitor cells and is chemotactic for mesenchymal cells and osteoblast-like cells for recruitment of osteogenic cells to sites of bone formation and remodeling (113). EGF and FGFs are other molecules with demonstrated involvement in the complex molecular cascades involved in cellular change $(128,129)$.

Implantation of rhBMP-2 resulted in early cartilage formation that was later replaced by bone tissue with bone marrow elements. Invasion of blood vessels into the cartilaginous anlagen lead to bone formation and bone marrow development (98). When larger doses of rhBMP2 were used, bone formation was observed concurrently with cartilage formation, suggesting bone induction through both endochondral and intramembranous pathways. BMPs are believed to act through chemotactic, mitogenic or differentiating mechanisms. It is important to understand that BMPs are not the only determinants of cell fates along the above-mentioned lineages. Specific nutrients, growth factors and cytokines at specific concentrations and in a specific sequence of exposures are fundamental for the bone formation process.

During fracture healing, BMP-2/4 affect precursor cells to become chondroblasts and express proteins needed for production of woven bone (121). When lamellar bone replaces woven bone, BMP expression is significantly reduced (130). rhBMP-2 can induce bony trabeculae and bone marrow (99) with concomitant shortening of the time required for osteogenesis and increased amount of bone formation (85). BMP-4 is also expressed in less differentiated cells at fracture healing during distraction osteogenesis (131). rhBMP-2 does not increase the mitotic activity of osteoblasts (132) and does not affect DNA synthesis, but rather initiates sequences of gene expression in these cells (133). rhBMP-2 up-regulates the expression of BMP3/4 mRNA (109) with a mechanism that probably augments the transcriptional rate of the gene rather than stabilizing the mRNA (33). Evidence of BMP-4 activating the transcriptional factors Msx-1/2 and Egr-1 in epithelialmesenchymal interactions during tooth development make this mechanism a valid working hypothesis (8). BMPs $1 / 2 / 4 / 6$ are expressed by osteoblasts before they form mineralized bone nodules and during expression of ALP, OC, OP (134), thereby becoming guiding factors in osteoprogenitor cells (106). Unlike the BMPs, the TGFßs do not induce ectopic bone formation and inhibit chondrogenesis $(63,110)$ but promote bone healing and fracture repair $(125,135)$. However, acting at the level of cell adhesion molecules (36), they may stimulate mesenchymal cell attraction and proliferation (136). Being part of a BMP-TGF $\beta$ heterodimer can amplify the BMP effect (137) especially at the early stages of the bone repair process $(61,138)$. BMP-2 up-regulates the phenotypic expression of osteoblasts $(82,83,133,139)$ and may indeed antagonize the repressing action of TGF- $\beta$ by cross-reacting with TGF- $\beta$ receptors (132). Additional studies have demonstrated a promotive effect of rhFGF (140) or prostaglandin E1 (PGE1) (123) on the action of BMPs, reducing the amount of growth factor needed to elicit a specific biologic response (141).

\section{Carriers}

The majority of studies investigating the role and action of exogenous BMPs use a matrix to deliver the growth factor to the implantation site. Although the matrix may not contribute any additional factors necessary for bone induction (107), it is a fundamental and very important component of the growth process. Collagenous or synthetic matrices have been used as delivery vehicles and their physicochemical properties, together with the microenvironment they create, play a role in the inductive outcome. Carriers can be solid xenogenic (HA) $(89,142)$, solid alloplastic (polyethylene polymers) materials $(143,144)$, or gels of autogenous $(88,145)$, allogenic $(146,147)$, or alloplastic origin (148), and combinations of the above (149).

One of the carrier functions is to maintain the factor at the site of implantation and thus enhance its local concentration. However, BMPs also help to stabilize the carrier by accelerating bone growth in its mass (150) due to the stabilization brough about by the BMPs absorption to the surface of the carrier matrix particles. As a result, $0.15 \mu \mathrm{g}$ of rhBMP-2 with matrix induced bone formation subcutaneously in rats, while a minimum of $75 \mu \mathrm{g}$ of rhBMP-2 was required in the absence of matrix (11). The isoelectric point and the structural features of the protein are important determinants of the implant-retained dose but the pharmacokinetics of the growth factor are not affected by carrier properties (151). Collagen matrix retains $\sim 65 \%$ of the BMPs during initial impregnation and releases it in two phases: an initial phase within hours of implantation and a second phase that depends on the nature of the carrier and its geometrical characteristics (152).

It is believed that BMPs do not bind to the carrier (152), but rather become physically entrapped in its structure which makes certain designs more favorable for bone induction over some others (153). In the case of collagen sponge carriers, the mass, collagen cross-linking and sterilization methods affect BMP precipitation and subsequent resistance of sponge degradation by collagenase (154). Properties of the best carrier may vary depending 
on the specific implantation site and the intended therapeutic outcome. Considerations include biodegradability, structural integrity, absence of immunogenicity, absorption and rate of release of BMP (155). The latter characteristic of the carrier serves its second function, which is controlled release of the BMP. This allows for a more constant and prolonged application. This renders BMPs more efficient and helps to create the chemotactic gradient, necessary for the cells to respond (11). BMP-2 is retained in a hydrogel carrier for more than 30 days whereas direct injection results in its complete elimination within 3 days (156). Collagen carrier also resulted in increased bone density of the regenerate when compared to polymeric matrix (157), emphasizing the importance of the structural properties of the carrier.

Recently, a novel approach has been suggested. This involves implanting matrices that actively concentrate native BMPs at the implantation site instead of passively storing and delivering rhBMPs which are a thousand times less potent that the native BMP complex (158). The matrix also serves as an environment in which bone can form and therefore helps to define the region in which new bone can be formed (159). Delivery vehicles with adequate structural consistency can function as primary scaffolds on which cells can attach and ECM, with subsequent mineralization, can be deposited $(152,160)$. If the delivery matrix can act as a scaffold, then the cartilaginous intermediate may not be necessary. Many investigators agree that it has not been proved definitively that the chondrogenic process is essential for bone formation by BMP $(89,161)$. The type of matrix used may also influence and determine the mechanism of bone formation that is appropriate for the implantation site (146). The material of the matrix and its geometrical parameters (pore size, and \%volume) are factors that directly (size of cells able to attach) or indirectly (effect on blood or oxygen supply) determine the microenvironment and influence the mechanism of bone formation (endochondral or intramembranous) $(59,89,90)$. BMPs combined with porous particles of hydroxyapatite or fibrous collagen membrane lead to intramembranous ossification $(89,142,161)$, whereas fibrous glass membrane or insoluble bone matrix support indirect bone formation $v i a$ a cartilaginous intermediate $(89,90,142)$.

In examining the action of BMPs, it is also important to consider dose-related effects. It is evident that various doses elicit different responses on specific cell types at different time intervals (162). The dose of the growth factor determines its chemotactic, proliferative or mitogenic signal and should therefore be well regulated. Increased BMP concentrations result in faster bone growth (11), with cartilage being more rapidly replaced by mineralized osteoid (163). rhBMPs in the form of monomers, homodimers or heterodimers need to be evaluated and standardized because they exhibit different biological potencies $(11,121)$.

The carrier may also act synergistically by serving as a reservoir of the inducible cell population. Bone marrow can be combined with BMPs (164) and, when providing its cellular component, can result in bone formation of superior performance. Recently, investigators attempted the direct (in vivo) or indirect (using viral vectors) delivery of BMP genomic sequences to the implantation site $(165,166)$, demonstrating active BMP expression for 2-6 weeks and bone formation with trabeculae and bone marrow. Cost of manufacturing and handling, in addition to ease of clinical application, are equally important factors to consider when deciding on a specific type of delivery vehicle.

\section{Clinical applications}

BMPs are of tremendous interest as therapeutic agents for healing bone fractures, preventing osteoporosis, treating periodontal bone defects and enhancing bone response around alloplastic materials implanted in bone (3). rhBMP2 delivered with an absorbable collagen sponge (ACS) has been used for the augmentation of the maxillary sinus floor in humans (167). An rhBMP-2 dose ranging from 1.77 to $3.4 \mathrm{mg}$ per patient generated an average of $8.51 \mathrm{~mm}$ of vertical bone height in four months providing a promising alternative to traditional grafting procedures (167). Similar results were also achieved in sub-antral augmentation of non-human primates with $6 \mathrm{~mm}$ of vertical bone gain and increased density that allowed placement of titanium implants (168). BMP-2 regenerated bone in irradiated tissues also provides the clinical potential to treat patients who have undergone radiation therapy and need bone reconstruction (169).

Periodontal regeneration was achieved when rhBMP-2 was applied to the defect site with a collagen membrane or a collagen gel. However, better results were obtained using the slower dissolving collagen membrane that allowed delivery of the growth factor for a prolonged period of time (170). The clinical outcome was a decreased depth of the defect site brought about by stimulating vertical bone growth and regenerating the periodontal attachment, provided that adequate space is maintained (171-175). The type of carrier, the time of treatment and the use of a barrier membrane are critical factors influencing the therapeutic outcome in cases of bone regeneration around dental implants (157) and have been shown to produce accelerated healing time as well as improved bone-implant contact levels (175-179). Moreover, alveolar ridge 
preservation or localized augmentation have been documented in humans (180).

Animal studies also suggest that rhBMP-2/ACS may be an effective treatment for the restoration of segmental bone defects $(181,182)$ and could lead to increased callus volume (183), strength and stiffness (184). A bioerodible polymeric carrier was used to deliver rhBMP-2 in a large segmental defect that was stabilized with stainless steel plates (185). Stabilization was necessary because of the large size of the animals (sheep) but it could have also helped to provide a stable environment for bone bridging since the carrier was reported to fragment easily. In a similar study in rabbits, porous poly-lactic acid carrier combined with rhBMP-2 was found to restore cortical bone with marrow elements in a twenty-millimeter long segmental defect (186). Skull defects were also filled with regenerated bone when BMPs were delivered in combination with hydroxyapatite $(2,187)$, a biodegradable gelatin hydrogel or an aqueous solution (188). Spinal fusion was significantly enhanced when rhBMP-2 was administered with a hydroxyapatite graft or a collagen gel, and demineralized bone matrix revealed improved biomechanical properties and enhanced radiographic and histologic appearance (189).

Although purification and characterization of rhBMP2 has been described in the Chinese hamster ovary (CHO) cell line (64) rendering BMPs available in large quantities, the fact that their inductive activity is ten times less than that of purified BMPs may present a limitation for their clinical application (190). Combinations of BMPs with other growth factors or biologic molecules forming heterodimers with twenty times higher potency in some cases (191) than homodimeric forms, hold a promising future in the field of bioengineering.

The parameter of host age further affects the biologic potential of many growth factors (161). The bone inductive ability of BMP-2 is diminished in older organisms and higher doses are required to induce the bone formation effect (192). Reduced migration of mesenchymal cells, lower levels of local anabolic agents, age associated reduction of receptor levels and compromised vascularization are some of the aspects to take into consideration (193-195). In the future, delivery of biological agents that control the regulators of BMPs may be of clinical significance in cases where BMP action needs to be halted to prevent pathological or hazardous ossification, such as after total hip or temporomadibular arthroplasties (44). Production of natural autogenous bone in moulds may allow a more efficient reconstruction of defects and deformities.

\section{References}

1. Urist MR (1965) Bone: formation by autoinduction. Science 150, 893-899

2. Ripamonti U, Reddi AH (1992) Growth and morphogenetic factors in bone induction: role of osteogenin and related bone morphogenetic proteins in craniofacial and periodontal bone repair. Crit Rev Oral Biol Med 3, 1-14

3. Ripamonti U, Reddi AH (1997) Tissue engineering, morphogenesis, and regeneration of the periodontal tissues by bone morphogenetic proteins. Crit Rev Oral Biol Med 8, 154-163

4. Jones CM, Lyons KM, Lapan PM, Wright CV, Hogan BL (1992) DVR-4 (bone morphogenetic protein-4) as a posterior-ventralizing factor in Xenopus mesoderm induction. Development 115, 639-647

5. Zou H, Niswander L (1996) Requirement for BMP signaling in interdigital apoptosis and scale formation [see comments]. Science 272, 738-741

6. Paralkar VM, Weeks BS, Yu YM, Kleinman HK, Reddi AH (1992) Recombinant human bone morphogenetic protein 2B stimulates PC12 cell differentiation: potentiation and binding to type IV collagen. J Cell Biol 119, 1721-1728

7. Shah NM, Groves AK, Anderson DJ (1996) Alternative neural crest cell fates are instructively promoted by TGFbeta superfamily members. Cell 85, 331-343

8. Vainio S, Karavanova I, Jowett A, Thesleff I (1993) Identification of BMP-4 as a signal mediating secondary induction between epithelial and mesenchymal tissues during early tooth development. Cell 75, 45-58

9. Cheifetz, S. BMP receptors in limb and tooth formation. Critical Reviews in Oral Biology and Medicine 10(2), 182-198. 1999.

10. Centrella M, Horowitz MC, Wozney JM, McCarthy TL (1994) Transforming growth factor-beta gene family members and bone. Endocr Rev 15, 27-39

11. Wang EA (1993) Bone morphogenetic proteins (BMPs): therapeutic potential in healing bony defects. Trends Biotechnol 11, 379-383

12. Wozney JM, Rosen V, Celeste AJ, Mitsock LM, Whitters MJ, Kriz RW, Hewick RM, Wang EA (1988) Novel regulators of bone formation: molecular clones and activities. Science 242, 15281534

13. Ruppert R, Hoffmann E, Sebald W (1996) Human bone morphogenetic protein 2 contains a heparinbinding site which modifies its biological activity. 
Eur J Biochem 237, 295-302

14. Massague J, Weis-Garcia F (1996) Serine/threonine kinase receptors: mediators of transforming growth factor beta family signals. Cancer Surv 27, 41-64

15. Attisano L, Wrana JL, Lopez-Casillas F, Massague J (1994) TGF-beta receptors and actions. Biochim Biophys Acta 1222, 71-80

16. Nohno T, Ishikawa T, Saito T, Hosokawa K, Noji S, Wolsing DH, Rosenbaum JS (1995) Identification of a human type II receptor for bone morphogenetic protein- 4 that forms differential heteromeric complexes with bone morphogenetic protein type I receptors. J Biol Chem 270, 22522-22526

17. Yamashita H, Ten D, Heldin CH, Miyazono K (1996) Bone morphogenetic protein receptors. Bone $19,569-574$

18. Lin HY, Wang XF, Ng-Eaton E, Weinberg RA, Lodish HF (1992) Expression cloning of the TGFbeta type II receptor, a functional transmembrane serine/threonine kinase [published erratum appears in Cell 1992 Sep 18;70(6):following 1068]. Cell 68, 775-785

19. Wozney JM (1992) The bone morphogenetic protein family and osteogenesis. Mol Reprod Dev 32, 160167

20. Ten D, Yamashita H, Sampath TK, Reddi AH, Estevez M, Riddle DL, Ichijo H, Heldin CH, Miyazono K (1994) Identification of type I receptors for osteogenic protein-1 and bone morphogenetic protein-4. J Biol Chem 269, 16985-16988

21. Kretzschmar M, Liu F, Hata A, Doody J, Massague J (1997) The TGF-beta family mediator Smad1 is phosphorylated directly and activated functionally by the BMP receptor kinase. Genes Dev 11, 984995

22. Hoodless PA, Haerry T, Abdollah S, Stapleton M, O'Connor MB, Attisano L, Wrana JL (1996) MADR1, a MAD-related protein that functions in BMP2 signaling pathways. Cell 85, 489-500

23. Thomsen GH (1996) Xenopus mothers against decapentaplegic is an embryonic ventralizing agent that acts downstream of the BMP-2/4 receptor. Development 122, 2359-2366

24. Baker JC, Harland RM (1996) A novel mesoderm inducer, Madr2, functions in the activin signal transduction pathway. Genes Dev 10, 1880-1889

25. Chen X, Rubock MJ, Whitman M (1996) A transcriptional partner for MAD proteins in TGFbeta signalling [published erratum appears in Nature 1996 Dec 19-26;384(6610):648]. Nature 383, 691696
26. Liu F, Hata A, Baker JC, Doody J, Carcamo J, Harland RM, Massague J (1996) A human Mad protein acting as a BMP-regulated transcriptional activator [see comments]. Nature 381, 620-623

27. Sakou T, Onishi T, Yamamoto T, Nagamine T, Sampath T, Ten D (1999) Localization of Smads, the TGF-beta family intracellular signaling components during endochondral ossification. J Bone Miner Res 14, 1145-1152

28. Ishisaki A, Yamato K, Hashimoto S, Nakao A, Tamaki K, Nonaka K, Ten D, Sugino H, Nishihara T (1999) Differential inhibition of Smad6 and Smad7 on bone morphogenetic protein- and activinmediated growth arrest and apoptosis in B cells. J Biol Chem 274, 13637-13642

29. Fujii M, Takeda K, Imamura T, Aoki H, Sampath TK, Enomoto S, Kawabata M, Kato M, Ichijo H, Miyazono K (1999) Roles of bone morphogenetic protein type I receptors and smad proteins in osteoblast and chondroblast differentiation [In Process Citation]. Mol Biol Cell 10, 3801-3813

30. Grieder NC, Nellen D, Burke R, Basler K, Affolter M (1995) Schnurri is required for Drosophila Dpp signaling and encodes a zinc finger protein similar to the mammalian transcription factor PRDII-BF1. Cell 81, 791-800

31. Yamaguchi K, Shirakabe K, Shibuya H, Irie K, Oishi I, Ueno N, Taniguchi T, Nishida E, Matsumoto K (1995) Identification of a member of the MAPKKK family as a potential mediator of TGFbeta signal transduction. Science 270, 2008-2011

32. Ogata T, Wozney JM, Benezra R, Noda M (1993) Bone morphogenetic protein 2 transiently enhances expression of a gene, Id (inhibitor of differentiation), encoding a helix-loop-helix molecule in osteoblastlike cells. Proc Natl Acad Sci U S A 90, 9219-9222

33. Palcy S, Goltzman D (1999) Protein kinase signalling pathways involved in the up-regulation of the rat alpha1(I) collagen gene by transforming growth factor beta1 and bone morphogenetic protein 2 in osteoblastic cells. Biochem J 343, 21-27

34. Ebisawa T, Tada K, Kitajima I, Tojo K, Sampath TK, Kawabata M, Miyazono K, Imamura T (1999) Characterization of bone morphogenetic protein-6 signaling pathways in osteoblast differentiation. $\mathrm{J}$ Cell Sci 112, 3519-3527

35. Xu RH, Dong Z, Maeno M, Kim J, Suzuki A, Ueno N, Sredni D, Colburn NH, Kung HF (1996) Involvement of Ras/Raf/AP-1 in BMP-4 signaling during Xenopus embryonic development. Proc Natl Acad Sci U S A 93, 834-838 
36. Nissinen L, Pirila L, Heino J (1997) Bone morphogenetic protein-2 is a regulator of cell adhesion. Exp Cell Res 230, 377-385

37. Jikko A, Harris SE, Chen D, Mendrick DL, Damsky $\mathrm{CH}$ (1999) Collagen integrin receptors regulate early osteoblast differentiation induced by BMP-2. J Bone Miner Res 14, 1075-1083

38. Haas AR, Tuan RS (1999) Chondrogenic differentiation of murine $\mathrm{C} 3 \mathrm{H} 10 \mathrm{~T} 1 / 2$ multipotential mesenchymal cells: II. Stimulation by bone morphogenetic protein-2 requires modulation of $\mathrm{N}$-cadherin expression and function. Differentiation 64, 77-89

39. Cheng SL, Lecanda F, Davidson MK, Warlow PM, Zhang SF, Zhang L, Suzuki S, St J, Civitelli R (1998) Human osteoblasts express a repertoire of cadherins, which are critical for BMP-2-induced osteogenic differentiation. J Bone Miner Res 13, 633644

40. Duprez DM, Coltey M, Amthor H, Brickell PM, Tickle C (1996) Bone morphogenetic protein-2 (BMP-2) inhibits muscle development and promotes cartilage formation in chick limb bud cultures. Dev Biol 174, 448-452

41. Bitgood MJ, McMahon AP (1995) Hedgehog and Bmp genes are coexpressed at many diverse sites of cell-cell interaction in the mouse embryo. Dev Biol 172, 126-138

42. Ghosh-Choudhury N, Harris MA, Feng JQ, Mundy GR, Harris SE (1994) Expression of the BMP 2 gene during bone cell differentiation. Crit Rev Eukaryot Gene Expr 4, 345-355

43. Heller LC, Li Y, Abrams KL, Rogers MB (1999) Transcriptional regulation of the Bmp2 gene. Retinoic acid induction in F9 embryonal carcinoma cells and Saccharomyces cerevisiae. J Biol Chem 274, 1394-1400

44. Schmitt JM, Hwang K, Winn SR, Hollinger JO (1999) Bone morphogenetic proteins: an update on basic biology and clinical relevance. J Orthop Res 17, 269-278

45. Iemura S, Yamamoto TS, Takagi C, Kobayashi H, Ueno N (1999) Isolation and characterization of bone morphogenetic protein-binding proteins from the early Xenopus embryo. J Biol Chem 274, 2684326849

46. Mabie PC, Mehler MF, Kessler JA (1999) Multiple roles of bone morphogenetic protein signaling in the regulation of cortical cell number and phenotype. J Neurosci 19, 7077-7088

47. Leclerc C, Duprat AM, Moreau M (1999) Noggin upregulates Fos expression by a calcium-mediated pathway in amphibian embryos. Dev Growth Differ 41, 227-238

48. Ito H, Akiyama H, Shigeno C, Nakamura T (1999) Noggin and bone morphogenetic protein- 4 coordinately regulate the progression of chondrogenic differentiation in mouse clonal EC cells, ATDC5. Biochem Biophys Res Commun 260, 240-244

49. Gazzerro E, Gangji V, Canalis E (1998) Bone morphogenetic proteins induce the expression of noggin, which limits their activity in cultured rat osteoblasts. J Clin Invest 102, 2106-2114

50. Carrington JL, Reddi AH (1991) Parallels between development of embryonic and matrix-induced endochondral bone. Bioessays 13, 403-408

51. Hall BK (1991) Cellular interactions during cartilage and bone development [see comments]. J Craniofac Genet Dev Biol 11, 238-250

52. Hall BK, Miyake T (1992) The membranous skeleton: the role of cell condensations in vertebrate skeletogenesis. Anat Embryol (Berl) 186, 107-124

53. Hall BK, Miyake T (1995) Divide, accumulate, differentiate: cell condensation in skeletal development revisited. Int J Dev Biol 39, 881-893

54. Hall BK, Ekanayake S (1991) Effects of growth factors on the differentiation of neural crest cells and neural crest cell-derivatives. Int J Dev Biol 35, 367387

55. Hall BK (1990) Evolutionary issues in craniofacial biology. Cleft Palate J 27, 95-100

56. Carrington JL, Chen P, Yanagishita M, Reddi AH (1991) Osteogenin (bone morphogenetic protein-3) stimulates cartilage formation by chick limb bud cells in vitro. Dev Biol 146, 406-415

57. Boden SD, Hair G, Titus L, Racine M, McCuaig K, Wozney JM, Nanes MS (1997) Glucocorticoidinduced differentiation of fetal rat calvarial osteoblasts is mediated by bone morphogenetic protein-6. Endocrinology 138, 2820-2828

58. Langille RM (1994) In vitro analysis of the spatial organization of chondrogenic regions of avian mandibular mesenchyme. Dev Dyn 201, 55-62

59. Katoh R, Urist MR (1993) Surface adhesion and attachment factors in bone morphogenetic proteininduced chondrogenesis in vitro. Clin Orthop295304

60. Rosen V, Nove J, Song JJ, Thies RS, Cox K, Wozney JM (1994) Responsiveness of clonal limb bud cell lines to bone morphogenetic protein 2 reveals a sequential relationship between cartilage and bone 
cell phenotypes. J Bone Miner Res 9, 1759-1768

61. Lyons KM, Pelton RW, Hogan BL (1990) Organogenesis and pattern formation in the mouse: RNA distribution patterns suggest a role for bone morphogenetic protein-2A (BMP-2A). Development 109, 833-844

62. Reddi AH, Cunningham NS (1993) Initiation and promotion of bone differentiation by bone morphogenetic proteins. J Bone Miner Res 8 Suppl 2, S499-S502

63. Reddi AH (1994) Bone and cartilage differentiation. Curr Opin Genet Dev 4, 737-744

64. Wang EA, Rosen V, D’Alessandro JS, Bauduy M, Cordes P, Harada T, Israel DI, Hewick RM, Kerns KM, LaPan P, et a (1990) Recombinant human bone morphogenetic protein induces bone formation. Proc Natl Acad Sci USA 87, 2220-2224

65. Vukicevic S, Luyten FP, Reddi AH (1989) Stimulation of the expression of osteogenic and chondrogenic phenotypes in vitro by osteogenin. Proc Natl Acad Sci USA 86, 8793-8797

66. Ahrens M, Ankenbauer T, Schroder D, Hollnagel A, Mayer H, Gross G (1993) Expression of human bone morphogenetic proteins- 2 or -4 in murine mesenchymal progenitor $\mathrm{C} 3 \mathrm{H} 10 \mathrm{~T} 1 / 2$ cells induces differentiation into distinct mesenchymal cell lineages. DNA Cell Biol 12, 871-880

67. Volek-Smith H, Urist MR (1996) Recombinant human bone morphogenetic protein (rhBMP) induced heterotopic bone development in vivo and in vitro. Proc Soc Exp Biol Med 211, 265-272

68. Gross RE, Mehler MF, Mabie PC, Zang Z, Santschi L, Kessler JA (1996) Bone morphogenetic proteins promote astroglial lineage commitment by mammalian subventricular zone progenitor cells. Neuron 17, 595-606

69. Rickard DJ, Sullivan TA, Shenker BJ, Leboy PS, Kazhdan I (1994) Induction of rapid osteoblast differentiation in rat bone marrow stromal cell cultures by dexamethasone and BMP-2. Dev Biol $161,218-228$

70. Becerra J, Andrades JA, Ertl DC, Sorgente N, Nimni ME (1996) Demineralized bone matrix mediates differentiation of bone marrow stromal cells in vitro: effect of age of cell donor. J Bone Miner Res 11, 1703-1714

71. Wang EA, Israel DI, Kelly S, Luxenberg DP (1993) Bone morphogenetic protein-2 causes commitment and differentiation in $\mathrm{C} 3 \mathrm{H} 10 \mathrm{~T} 1 / 2$ and 3T3 cells. Growth Factors 9, 57-71

72. Valcourt U, Ronziere MC, Winkler P, Rosen V,
Herbage D, Mallein-Gerin F (1999) Different effects of bone morphogenetic proteins 2, 4, 12, and 13 on the expression of cartilage and bone markers in the MC615 chondrocyte cell line. Exp Cell Res 251, 264274

73. Thies RS, Bauduy M, Ashton BA, Kurtzberg L, Wozney JM, Rosen V (1992) Recombinant human bone morphogenetic protein-2 induces osteoblastic differentiation in W-20-17 stromal cells. Endocrinology 130, 1318-1324

74. Hall BK (1970) Cellular differentiation in skeletal tissues. Biol Rev Camb Philos Soc 45, 455-484

75. Boyan BD, Caplan AI, Heckman JD, Lennon DP, Ehler W, Schwartz Z (1999) Osteochondral progenitor cells in acute and chronic canine nonunions. J Orthop Res 17, 246-255

76. Stutzmann JJ, Petrovic AG (1982) Bone cell histogenesis: the skeletoblast as a stem-cell for preosteoblasts and for secondary-type prechondroblasts. Prog Clin Biol Res 101, 29-43

77. Petrovic AG (1982) Postnatal growth of bone: a perspective of current trends, new approaches, and innovations. Prog Clin Biol Res 101, 297-331

78. Petrovic AG (1972) Mechanisms and regulation of mandibular condylar growth. Acta Morphol Neerl Scand 10, 25-34

79. Langille RM (1994) Chondrogenic differentiation in cultures of embryonic rat mesenchyme. Microsc Res Tech 28, 455-469

80. Lyons KM, Pelton RW, Hogan BL (1989) Patterns of expression of murine Vgr-1 and BMP-2a RNA suggest that transforming growth factor-beta-like genes coordinately regulate aspects of embryonic development. Genes Dev 3, 1657-1668

81. Hiraki Y, Inoue H, Shigeno C, Sanma Y, Bentz H, Rosen DM, Asada A, Suzuki F (1991) Bone morphogenetic proteins (BMP-2 and BMP-3) promote growth and expression of the differentiated phenotype of rabbit chondrocytes and osteoblastic MC3T3-E1 cells in vitro. J Bone Miner Res 6, 1373-1385

82. Chen TL, Bates RL, Dudley A, Hammonds RGJ, Amento EP (1991) Bone morphogenetic protein-2b stimulation of growth and osteogenic phenotypes in rat osteoblast-like cells: comparison with TGF-beta 1. J Bone Miner Res 6, 1387-1393

83. Yamaguchi A, Katagiri T, Ikeda T, Wozney JM, Rosen V, Wang EA, Kahn AJ, Suda T, Yoshiki S (1991) Recombinant human bone morphogenetic protein-2 stimulates osteoblastic maturation and inhibits myogenic differentiation in vitro. J Cell 
Biol 113, 681-687

84. Chen P, Carrington JL, Hammonds RG, Reddi AH (1991) Stimulation of chondrogenesis in limb bud mesoderm cells by recombinant human bone morphogenetic protein $2 \mathrm{~B}$ (BMP-2B) and modulation by transforming growth factor beta 1 and beta 2. Exp Cell Res 195, 509-515

85. Iwasaki M, Nakahara H, Nakase T, Kimura T, Takaoka K, Caplan AI, Ono K (1994) Bone morphogenetic protein 2 stimulates osteogenesis but does not affect chondrogenesis in osteochondrogenic differentiation of periosteumderived cells. J Bone Miner Res 9, 1195-1204

86. Raval P, Hsu HH, Schneider DJ, Sarras MPJ, Masuhara K, Bonewald LF, Anderson HC (1996) Expression of bone morphogenetic proteins by osteoinductive and non-osteoinductive human osteosarcoma cells. J Dent Res 75, 1518-1523

87. Puleo DA (1997) Dependence of mesenchymal cell responses on duration of exposure to bone morphogenetic protein-2 in vitro. $\mathrm{J}$ Cell Physiol 173, 93-101

88. Sweeney TM, Opperman LA, Persing JA, Ogle RC (1995) Repair of critical size rat calvarial defects using extracellular matrix protein gels. J Neurosurg 83, 710-715

89. Kuboki Y, Saito T, Murata M, Takita H, Mizuno M, Inoue M, Nagai N, Poole AR (1995) Two distinctive $\mathrm{BMP}$-carriers induce zonal chondrogenesis and membranous ossification, respectively; geometrical factors of matrices for cell-differentiation. Connect Tissue Res 32, 219-226

90. Sasano Y, Mizoguchi I, Takahashi I, Kagayama M, Saito T, Kuboki Y (1997) BMPs induce endochondral ossification in rats when implanted ectopically within a carrier made of fibrous glass membrane. Anat Rec 247, 472-478

91. Yoshida K, Bessho K, Fujimura K, Kusumoto K, Ogawa Y, Tani Y, Iizuka T (1998) Osteoinduction capability of recombinant human bone morphogenetic protein-2 in intramuscular and subcutaneous sites: an experimental study. J Craniomaxillofac Surg 26, 112-115

92. Zanetti NC, Solursh M (1984) Induction of chondrogenesis in limb mesenchymal cultures by disruption of the actin cytoskeleton. J Cell Biol 99, 115-123

93. Aikawa T, Shirasuna K, Iwamoto M, Watatani K, Nakamura T, Okura M, Yoshioka H, Matsuya T (1996) Establishment of bone morphogenetic protein 2 responsive chondrogenic cell line. J Bone Miner
Res 11, 544-553

94. Kato Y, Iwamoto M, Koike T, Suzuki F, Takano Y (1988) Terminal differentiation and calcification in rabbit chondrocyte cultures grown in centrifuge tubes: regulation by transforming growth factor beta and serum factors. Proc Natl Acad Sci USA 85, 9552-9556

95. Wu LN, Sauer GR, Genge BR, Wuthier RE (1989) Induction of mineral deposition by primary cultures of chicken growth plate chondrocytes in ascorbatecontaining media. Evidence of an association between matrix vesicles and collagen. J Biol Chem 264, 21346-21355

96. Shukunami C, Ohta Y, Sakuda M, Hiraki Y (1998) Sequential progression of the differentiation program by bone morphogenetic protein-2 in chondrogenic cell line ATDC5. Exp Cell Res 241, 1-11

97. Schwartz Z, Sylvia VL, Liu Y, Dean DD, Boyan BD (1998) Treatment of resting zone chondrocytes with bone morphogenetic protein- 2 induces maturation into a phenotype characteristic of growth zone chondrocytes by downregulating responsiveness to $24,25(\mathrm{OH}) 2 \mathrm{D} 3$ and upregulating responsiveness to 1,25-(OH)2D3. Endocrine 9, 273-280

98. Kawai M, Hattori H, Yasue K, Mizutani H, Ueda M, Kaneda T, Hoshino T (1994) Development of hemopoietic bone marrow within the ectopic bone induced by bone morphogenetic protein. Blood Cells 20, 191-191

99. Kusumoto K, Bessho K, Fujimura K, Konishi Y, Ogawa Y, lizuka T (1995) Comparative study of bone marrow induced by purified BMP and recombinant human BMP-2. Biochem Biophys Res Commun 215, 205-211

100. Knutsen R, Wergedal JE, Sampath TK, Baylink DJ, Mohan S (1993) Osteogenic protein-1 stimulates proliferation and differentiation of human bone cells in vitro. Biochem Biophys Res Commun 194, 1352-1358

101. Maiti SK, Singh GR (1998) Bone morphogenetic proteins - novel regulators of bone formation. Indian J Exp Biol 36, 237-244

102. Grimsrud CD, Romano PR, D’Souza M, Puzas JE, Reynolds PR, Rosier RN, O'Keefe RJ (1999) BMP6 is an autocrine stimulator of chondrocyte differentiation. J Bone Miner Res 14, 475-482

103. Gazzerro E, Rydziel S, Canalis E (1999) Skeletal bone morphogenetic proteins suppress the expression of collagenase- 3 by rat osteoblasts. Endocrinology $140,562-567$

104. Komaki M, Katagiri T, Suda T (1996) Bone 
morphogenetic protein-2 does not alter the differentiation pathway of committed progenitors of osteoblasts and chondroblasts. Cell Tissue Res 284, 9-17

105. Asahina I, Sampath TK, Nishimura I, Hauschka PV (1993) Human osteogenic protein-1 induces both chondroblastic and osteoblastic differentiation of osteoprogenitor cells derived from newborn rat calvaria. J Cell Biol 123, 921-933

106. Hughes FJ, Collyer J, Stanfield M, Goodman SA (1995) The effects of bone morphogenetic protein$2,-4$, and -6 on differentiation of rat osteoblast cells in vitro. Endocrinology 136, 2671-2677

107. Wozney JM, Rosen V, Byrne M, Celeste AJ, Moutsatsos I, Wang EA (1990) Growth factors influencing bone development. J Cell Sci Suppl 13, 149-156

108. Li IW, Cheifetz S, McCulloch CA, Sampath KT, Sodek J (1996) Effects of osteogenic protein-1 (OP1, BMP-7) on bone matrix protein expression by fetal rat calvarial cells are differentiation stage specific. J Cell Physiol 169, 115-125

109. Chen D, Harris MA, Rossini G, Dunstan CR, Dallas SL, Feng JQ, Mundy GR, Harris SE (1997) Bone morphogenetic protein 2 (BMP-2) enhances BMP3, BMP-4, and bone cell differentiation marker gene expression during the induction of mineralized bone matrix formation in cultures of fetal rat calvarial osteoblasts. Calcif Tissue Int 60, 283-290

110. Cheifetz S, Li IW, McCulloch CA, Sampath K, Sodek J (1996) Influence of osteogenic protein-1 (OP-1;BMP-7) and transforming growth factor-beta 1 on bone formation in vitro. Connect Tissue Res 35, $71-78$

111. Baylink DJ, Finkelman RD, Mohan S (1993) Growth factors to stimulate bone formation. J Bone Miner Res 8 Suppl 2, S565-S572

112. Paralkar VM, Nandedkar AK, Pointer RH, Kleinman HK, Reddi AH (1990) Interaction of osteogenin, a heparin binding bone morphogenetic protein, with type IV collagen. J Biol Chem 265, 17281-17284

113. Linkhart TA, Mohan S, Baylink DJ (1996) Growth factors for bone growth and repair: IGF, TGF beta and BMP. Bone 19, 1S-12S

114. Suzawa M, Takeuchi Y, Fukumoto S, Kato S, Ueno N, Miyazono K, Matsumoto T, Fujita T (1999) Extracellular matrix-associated bone morphogenetic proteins are essential for differentiation of murine osteoblastic cells in vitro. Endocrinology 140, 21252133

115. Frost HM (1965) An analysis of the relative complexity of cell system dynamics in bone. Henry Ford Hosp Med J 13, 271-283

116. Lind M, Deleuran B, Thestrup-Pedersen K, Soballe K, Eriksen EF, Bunger C (1995) Chemotaxis of human osteoblasts. Effects of osteotropic growth factors. APMIS 103, 140-146

117. Lind M (1998) Growth factor stimulation of bone healing. Effects on osteoblasts, osteomies, and implants fixation. Acta Orthop Scand Suppl 283, 237

118. Koide M, Murase Y, Yamato K, Noguchi T, Okahashi N, Nishihara T (1999) Bone morphogenetic protein2 enhances osteoclast formation mediated by interleukin-1alpha through upregulation of osteoclast differentiation factor and cyclooxygenase-2. Biochem Biophys Res Commun 259, 97-102

119. Caplan AI, Goldberg VM (1999) Principles of tissue engineered regeneration of skeletal tissues [In Process Citation]. Clin OrthopS12-S16

120. Caplan AI, Elyaderani M, Mochizuki Y, Wakitani S, Goldberg VM (1997) Principles of cartilage repair and regeneration. Clin Orthop254-269

121. Bostrom MP, Lane JM, Berberian WS, Missri AA, Tomin E, Weiland A, Doty SB, Glaser D, Rosen VM (1995) Immunolocalization and expression of bone morphogenetic proteins 2 and 4 in fracture healing. J Orthop Res 13, 357-367

122. Simmons DJ (1985) Fracture healing perspectives. Clin Orthop100-113

123. Ono I, Inoue M, Kuboki Y (1996) Promotion of the osteogenetic activity of recombinant human bone morphogenetic protein by prostaglandin E1. Bone $19,581-588$

124. Reddi AH (1997) Bone morphogenetic proteins: an unconventional approach to isolation of first mammalian morphogens. Cytokine Growth Factor Rev 8, 11-20

125. Noda M, Camilliere JJ (1989) In vivo stimulation of bone formation by transforming growth factorbeta. Endocrinology 124, 2991-2994

126. Harris SE, Bonewald LF, Harris MA, Sabatini M, Dallas S, Feng JQ, Ghosh-Choudhury N, Wozney J, Mundy GR (1994) Effects of transforming growth factor beta on bone nodule formation and expression of bone morphogenetic protein 2, osteocalcin, osteopontin, alkaline phosphatase, and type I collagen mRNA in long-term cultures of fetal rat calvarial osteoblasts. J Bone Miner Res 9, 855-863

127. Zhou H, Hammonds RGJ, Findlay DM, Martin TJ, Ng KW (1993) Differential effects of transforming growth factor-beta 1 and bone morphogenetic protein 
4 on gene expression and differentiated function of preosteoblasts. J Cell Physiol 155, 112-119

128. Marie PJ, Hott M, Perheentupa J (1990) Effects of epidermal growth factor on bone formation and resorption in vivo. Am J Physiol 258, E275-E281

129. Canalis E, McCarthy TL, Centrella M (1989) The role of growth factors in skeletal remodeling. Endocrinol Metab Clin North Am 18, 903-918

130. Bostrom MP (1998) Expression of bone morphogenetic proteins in fracture healing. Clin OrthopS116-S123

131. Li G, Berven S, Simpson H, Triffitt JT (1998) Expression of BMP-4 mRNA during distraction osteogenesis in rabbits. Acta Orthop Scand 69, 420425

132. Chaudhari A, Ron E, Rethman MP (1997) Recombinant human bone morphogenetic protein2 stimulates differentiation in primary cultures of fetal rat calvarial osteoblasts. Mol Cell Biochem 167, 31-39

133. Takuwa Y, Ohse C, Wang EA, Wozney JM, Yamashita K (1991) Bone morphogenetic protein2 stimulates alkaline phosphatase activity and collagen synthesis in cultured osteoblastic cells, MC3T3-E1. Biochem Biophys Res Commun 174, 96-101

134. Harris SE, Sabatini M, Harris MA, Feng JQ, Wozney J, Mundy GR (1994) Expression of bone morphogenetic protein messenger RNA in prolonged cultures of fetal rat calvarial cells. J Bone Miner Res 9, 389-394

135. Joyce ME, Terek RM, Jingushi S, Bolander ME (1990) Role of transforming growth factor-beta in fracture repair. Ann N Y Acad Sci 593, 107-123

136. Riley EH, Lane JM, Urist MR, Lyons KM, Lieberman JR (1996) Bone morphogenetic protein2: biology and applications. Clin Orthop39-46

137. Sun Y, Zhang W, Ma F, Chen W, Hou S (1997) Evaluation of transforming growth factor beta and bone morphogenetic protein composite on healing of bone defects. Chin Med J (Engl) 110, 927-931

138. Si X, Jin Y, Yang L (1998) Induction of new bone by ceramic bovine bone with recombinant human bone morphogenetic protein 2 and transforming growth factor beta. Int J Oral Maxillofac Surg 27, 310-314

139. Ohta S, Hiraki Y, Shigeno C, Suzuki F, Kasai R, Ikeda T, Kohno H, Lee K, Kikuchi H, Konishi J, et a (1992) Bone morphogenetic proteins (BMP-2 and BMP-3) induce the late phase expression of the proto-oncogene c-fos in murine osteoblastic MC3T3-
E1 cells. FEBS Lett 314, 356-360

140. Ono I, Tateshita T, Takita H, Kuboki Y (1996) Promotion of the osteogenetic activity of recombinant human bone morphogenetic protein by basic fibroblast growth factor. J Craniofac Surg 7, 418-425

141. Ripamonti U, Duneas N, Van D, Bosch C, Crooks J (1997) Recombinant transforming growth factorbetal induces endochondral bone in the baboon and synergizes with recombinant osteogenic protein1 (bone morphogenetic protein-7) to initiate rapid bone formation. J Bone Miner Res 12, 1584-1595

142. Murata M, Inoue M, Arisue M, Kuboki Y, Nagai N (1998) Carrier-dependency of cellular differentiation induced by bone morphogenetic protein in ectopic sites. Int J Oral Maxillofac Surg 27, 391-396

143. Saito N, Okada T, Toba S, Miyamoto S, Takaoka K (1999) New synthetic absorbable polymers as BMP carriers: plastic properties of poly-D,L-lactic acidpolyethylene glycol block copolymers. J Biomed Mater Res 47, 104-110

144. Isobe M, Yamazaki Y, Mori M, Amagasa T (1999) Bone regeneration produced in rat femur defects by polymer capsules containing recombinant human bone morphogenetic protein-2. J Oral Maxillofac Surg 57, 695-8discussion

145. Schwartz Z, Somers A, Mellonig JT, Carnes DLJ, Wozney JM, Dean DD, Cochran DL, Boyan BD (1998) Addition of human recombinant bone morphogenetic protein-2 to inactive commercial human demineralized freeze-dried bone allograft makes an effective composite bone inductive implant material. J Periodontol 69, 1337-1345

146. Bax BE, Wozney JM, Ashhurst DE (1999) Bone morphogenetic protein-2 increases the rate of callus formation after fracture of the rabbit tibia. Calcif Tissue Int 65, 83-89

147. Viljanen VV, Lindholm TC, Gao TJ, Lindholm TS (1997) Low dosage of native allogeneic bone morphogenetic protein in repair of sheep calvarial defects. Int J Oral Maxillofac Surg 26, 389-393

148. Santos EM, Radin S, Shenker BJ, Shapiro IM, Ducheyne P (1998) Si-Ca-P xerogels and bone morphogenetic protein act synergistically on rat stromal marrow cell differentiation in vitro. J Biomed Mater Res 41, 87-94

149. Alpaslan C, Irie K, Takahashi K, Ohashi N, Sakai H, Nakajima T, Ozawa H (1996) Long-term evaluation of recombinant human bone morphogenetic protein-2 induced bone formation with a biologic and synthetic delivery system. $\mathrm{Br} \mathrm{J}$ 
Oral Maxillofac Surg 34, 414-418

150. Koempel JA, Patt BS, O’Grady K, Wozney J, Toriumi DM (1998) The effect of recombinant human bone morphogenetic protein- 2 on the integration of porous hydroxyapatite implants with bone. J Biomed Mater Res 41, 359-363

151. Uludag H, Friess W, Williams D, Porter T, Timony G, D'Augusta D, Blake C, Palmer R, Biron B, Wozney J (1999) rhBMP-collagen sponges as osteoinductive devices: effects of in vitro sponge characteristics and protein $\mathrm{pI}$ on in vivo rhBMP pharmacokinetics. Ann N Y Acad Sci 875, 369-378

152. Uludag H, D'Augusta D, Palmer R, Timony G, Wozney J (1999) Characterization of rhBMP-2 pharmacokinetics implanted with biomaterial carriers in the rat ectopic model. J Biomed Mater Res 46, 193-202

153. Tsuruga E, Takita H, Itoh H, Wakisaka Y, Kuboki Y (1997) Pore size of porous hydroxyapatite as the cell-substratum controls BMP-induced osteogenesis. J Biochem (Tokyo) 121, 317-324

154. Friess W, Uludag H, Foskett S, Biron R (1999) Bone regeneration with recombinant human bone morphogenetic protein-2 (rhBMP-2) using absorbable collagen sponges (ACS): influence of processing on ACS characteristics and formulation. Pharm Dev Technol 4, 387-396

155. Lane JM, Sandhu HS (1987) Current approaches to experimental bone grafting. Orthop Clin North Am $18,213-225$

156. Yamamoto M, Tabata Y, Ikada Y (1998) Ectopic bone formation induced by biodegradable hydrogels incorporating bone morphogenetic protein. J Biomater Sci Polym Ed 9, 439-458

157. Cochran DL, Nummikoski PV, Jones AA, Makins SR, Turek TJ, Buser D (1997) Radiographic analysis of regenerated bone around endosseous implants in the canine using recombinant human bone morphogenetic protein-2. Int J Oral Maxillofac Implants 12, 739-748

158. De G (1998) Carriers that concentrate native bone morphogenetic protein in vivo. Tissue Eng 4, 337341

159. Whang K, Tsai DC, Nam EK, Aitken M, Sprague SM, Patel PK, Healy KE (1998) Ectopic bone formation via rhBMP-2 delivery from porous bioabsorbable polymer scaffolds. J Biomed Mater Res 42, 491-499

160. Katoh T, Sato K, Kawamura M, Iwata H, Miura T (1993) Osteogenesis in sintered bone combined with bovine bone morphogenetic protein. Clin
Orthop266-275

161. Sasano Y, Ohtani E, Narita K, Kagayama M, Murata M, Saito T, Shigenobu K, Takita H, Mizuno M, Kuboki Y (1993) BMPs induce direct bone formation in ectopic sites independent of the endochondral ossification in vivo. Anat $\operatorname{Rec} 236,373-380$

162. Barlow AJ, Francis-West PH (1997) Ectopic application of recombinant BMP-2 and BMP-4 can change patterning of developing chick facial primordia. Development 124, 391-398

163. Aspenberg P, Jeppsson C, Wang JS, Bostrom M (1996) Transforming growth factor beta and bone morphogenetic protein 2 for bone ingrowth: a comparison using bone chambers in rats. Bone 19, 499-503

164. Lane JM, Yasko AW, Tomin E, Cole BJ, Waller S, Browne M, Turek T, Gross J (1999) Bone marrow and recombinant human bone morphogenetic protein-2 in osseous repair. Clin Orthop216-227

165. Niyibizi C, Baltzer A, Lattermann C, Oyama M, Whalen JD, Robbins PD, Evans CH (1998) Potential role for gene therapy in the enhancement of fracture healing. Clin OrthopS148-S153

166. Lou J, Xu F, Merkel K, Manske P (1999) Gene therapy: adenovirus-mediated human bone morphogenetic protein-2 gene transfer induces mesenchymal progenitor cell proliferation and differentiation in vitro and bone formation in vivo. J Orthop Res 17, 43-50

167. Boyne PJ, Marx RE, Nevins M, Triplett G, Lazaro E, Lilly LC, Alder M, Nummikoski P (1997) A feasibility study evaluating rhBMP-2/absorbable collagen sponge for maxillary sinus floor augmentation. Int $\mathbf{J}$ Periodontics Restorative Dent $17,11-25$

168. Hanisch O, Tatakis DN, Rohrer MD, Wohrle PS, Wozney JM, Wikesjo UM (1997) Bone formation and osseointegration stimulated by rhBMP-2 following subantral augmentation procedures in nonhuman primates. Int J Oral Maxillofac Implants $12,785-792$

169. Howard BK, Brown KR, Leach JL, Chang CH, Rosenthal DI (1998) Osteoinduction using bone morphogenic protein in irradiated tissue. Arch Otolaryngol Head Neck Surg 124, 985-988

170. King GN, King N, Hughes FJ (1998) Effect of two delivery systems for recombinant human bone morphogenetic protein- 2 on periodontal regeneration in vivo. J Periodontal Res 33, 226-236

171. Hanisch O, Tatakis DN, Boskovic MM, Rohrer MD, Wikesjo UM (1997) Bone formation and 
reosseointegration in peri-implantitis defects following surgical implantation of rhBMP-2. Int J Oral Maxillofac Implants 12, 604-610

172. Sigurdsson TJ, Nygaard L, Tatakis DN, Fu E, Turek TJ, Jin L, Wozney JM, Wikesjo UM (1996) Periodontal repair in dogs: evaluation of rhBMP-2 carriers. Int J Periodontics Restorative Dent 16, 524-537

173. Cochran DL, Schenk R, Buser D, Wozney JM, Jones AA (1999) Recombinant human bone morphogenetic protein-2 stimulation of bone formation around endosseous dental implants. $\mathbf{J}$ Periodontol 70, 139-150

174. Linde A, Hedner E (1995) Recombinant bone morphogenetic protein- 2 enhances bone healing, guided by osteopromotive e-PTFE membranes: an experimental study in rats. Calcif Tissue Int 56, $549-553$

175. Ripamonti U, Heliotis M, Van D, Reddi AH (1994) Bone morphogenetic proteins induce periodontal regeneration in the baboon (Papio ursinus) [published erratum appears in J Periodontal Res 1995 Mar;30(2):149-51]. J Periodontal Res 29, 439-445

176. Rutherford RB, Sampath TK, Rueger DC, Taylor TD (1992) Use of bovine osteogenic protein to promote rapid osseointegration of endosseous dental implants. Int J Oral Maxillofac Implants 7, 297-301

177. Sigurdsson TJ, Fu E, Tatakis DN, Rohrer MD, Wikesjo UM (1997) Bone morphogenetic protein2 for peri-implant bone regeneration and osseointegration. Clin Oral Implants Res 8, 367-374

178. Cook SD, Salkeld SL, Rueger DC (1995) Evaluation of recombinant human osteogenic protein-1 (rhOP1) placed with dental implants in fresh extraction sites. J Oral Implantol 21, 281-289

179. Yan J, Xiang W, Baolin L, White FH (1994) Early histologic response to titanium implants complexed with bovine bone morphogenetic protein. J Prosthet Dent 71, 289-294

180. Howell TH, Fiorellini J, Jones A, Alder M, Nummikoski P, Lazaro M, Lilly L, Cochran D (1997) A feasibility study evaluating rhBMP2/absorbable collagen sponge device for local alveolar ridge preservation or augmentation. Int $\mathrm{J}$ Periodontics Restorative Dent 17, 124-139

181. Hollinger JO, Schmitt JM, Buck DC, Shannon R, Joh SP, Zegzula HD, Wozney J (1998) Recombinant human bone morphogenetic protein- 2 and collagen for bone regeneration. J Biomed Mater Res 43, 356364

182. Yasko AW, Lane JM, Fellinger EJ, Rosen V, Wozney
JM, Wang EA (1992) The healing of segmental bone defects, induced by recombinant human bone morphogenetic protein (rhBMP-2). A radiographic, histological, and biomechanical study in rats [published erratum appears in J Bone Joint Surg Am 1992 Aug;74(7):1111]. J Bone Joint Surg Am 74, 659-670

183. Welch RD, Jones AL, Bucholz RW, Reinert CM, Tjia JS, Pierce WA, Wozney JM, Li XJ (1998) Effect of recombinant human bone morphogenetic protein2 on fracture healing in a goat tibial fracture model. J Bone Miner Res 13, 1483-1490

184. Stevenson S, Cunningham N, Toth J, Davy D, Reddi AH (1994) The effect of osteogenin (a bone morphogenetic protein) on the formation of bone in orthotopic segmental defects in rats. J Bone Joint Surg Am 76, 1676-1687

185. Kirker-Head CA, Gerhart TN, Armstrong R, Schelling SH, Carmel LA (1998) Healing bone using recombinant human bone morphogenetic protein 2 and copolymer. Clin Orthop205-217

186. Zegzula HD, Buck DC, Brekke J, Wozney JM, Hollinger JO (1997) Bone formation with use of rhBMP-2 (recombinant human bone morphogenetic protein-2). J Bone Joint Surg Am 79, 1778-1790

187. Ripamonti U, Ma SS, Van D, Reddi AH (1992) Osteogenin, a bone morphogenetic protein, adsorbed on porous hydroxyapatite substrata, induces rapid bone differentiation in calvarial defects of adult primates. Plast Reconstr Surg 90, 382-393

188. Hong L, Tabata Y, Yamamoto M, Miyamoto S, Yamada K, Hashimoto N, Ikada Y (1998) Comparison of bone regeneration in a rabbit skull defect by recombinant human BMP-2 incorporated in biodegradable hydrogel and in solution. J Biomater Sci Polym Ed 9, 1001-1014

189. Takahashi T, Tominaga T, Watabe N, Yokobori ATJ, Sasada H, Yoshimoto T (1999) Use of porous hydroxyapatite graft containing recombinant human bone morphogenetic protein- 2 for cervical fusion in a caprine model. J Neurosurg 90, 224-230

190. Bessho K, Kusumoto K, Fujimura K, Konishi Y, Ogawa Y, Tani Y, lizuka T (1999) Comparison of recombinant and purified human bone morphogenetic protein. Br J Oral Maxillofac Surg $37,2-5$

191. Israel DI, Nove J, Kerns KM, Kaufman RJ, Rosen V, Cox KA, Wozney JM (1996) Heterodimeric bone morphogenetic proteins show enhanced activity in vitro and in vivo. Growth Factors 13, 291-300

192. Nagai N, Qin CL, Nagatsuka H, Inoue M, Ishiwari 
Y (1999) Age effects on ectopic bone formation induced by purified bone morphogenetic protein. Int J Oral Maxillofac Surg 28, 143-150

193. Fleet JC, Cashman K, Cox K, Rosen V (1996) The effects of aging on the bone inductive activity of recombinant human bone morphogenetic protein2. Endocrinology 137, 4605-4610

194. Helm GA, Sheehan JM, Sheehan JP, Jane JAJ, diPierro CG, Simmons NE, Gillies GT, Kallmes DF, Sweeney TM (1997) Utilization of type I collagen gel, demineralized bone matrix, and bone morphogenetic protein-2 to enhance autologous bone lumbar spinal fusion [see comments]. J Neurosurg 86, 93-100

195. Sandhu HS, Kanim LE, Kabo JM, Toth JM, Zeegen EN, Liu D, Delamarter RB, Dawson EG (1996) Effective doses of recombinant human bone morphogenetic protein-2 in experimental spinal fusion. Spine 21, 2115-2122 